\title{
Splenic abscess due to acute pyelonephritis
}

\author{
Laura Iliescu, ${ }^{1}$ Carmen Orban ${ }^{2}$ Simona Ioanitescu, ${ }^{1}$ Letitia Toma ${ }^{1}$
}

1 Department of Internal Medicine, Fundeni Clinical Institute, Bucharest, Romania ${ }^{2}$ Department of Anesthesiology, Fundeni Clinical Institute, Bucharest, Romania

\section{Correspondence to}

Dr Laura lliescu,

laura_ate@yahoo.com

Accepted 23 May 2014

\section{DESCRIPTION}

We present a case of a 63-year-old woman with hypertension and diabetes mellitus, who was admitted for left lumbar pain, fever $\left(38.5^{\circ} \mathrm{C}\right)$ and nausea. Abdominal ultrasound revealed several heterogenous splenic nodules and an enlarged left kidney with a $7 \mathrm{~mm}$ calculus in the medium pyelocaliceal system. Contrast enhanced ultrasound showed multiple simple splenic cysts and a nodule in the inferior pole, with rapid arterial peripheral enhancement (figure 1A), enhancement in the late phase (figure 1B) without washout, with irregular contour, inner septum and possible central necrosis. Abdominal CT showed a $21 \mathrm{~mm}$, heterogeneous, hypodense nodule in the inferior splenic pole (figure 2A), and inflammatory densification of perirenal fatty tissue with thickening of the perirenal fascia (figure 2B).
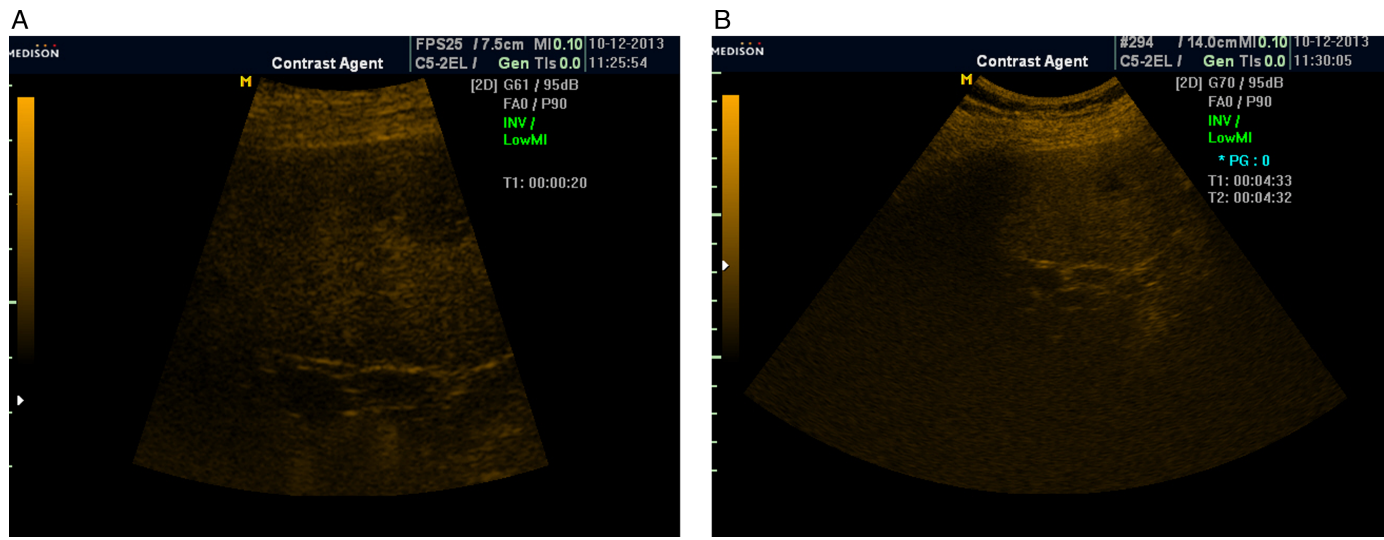

Figure 1 (A) Arterial phase of contrast enhanced ultrasound (CEUS) and (B) late phase of CEUS. improved in about 2 weeks. considered. $^{3}$
Biologically, the patient presented with leukocytosis, hyperglycaemia and inflammatory syndrome. Urinary cultures were negative; blood cultures grew Streptococcus spp. The patient received antibiotic treatment and the symptoms and ultrasound aspect

We conclude that the patient presented splenic abscess due to acute pyelonephritis. Diabetes is a risk factor for this rare condition; splenic abscesses may appear by haematogenous metastasis or contiguity. ${ }^{1}$ Other cases ${ }^{2}$ showed improved outcome by splenectomy; in our case this was not required, as the patient's evolution was satisfactory under antibiotic treatment. Although there are no pathognomonic symptoms, in patients with high suspicion of infection who present with abdominal pain, fever and nausea, splenic abscesses are diagnoses to be
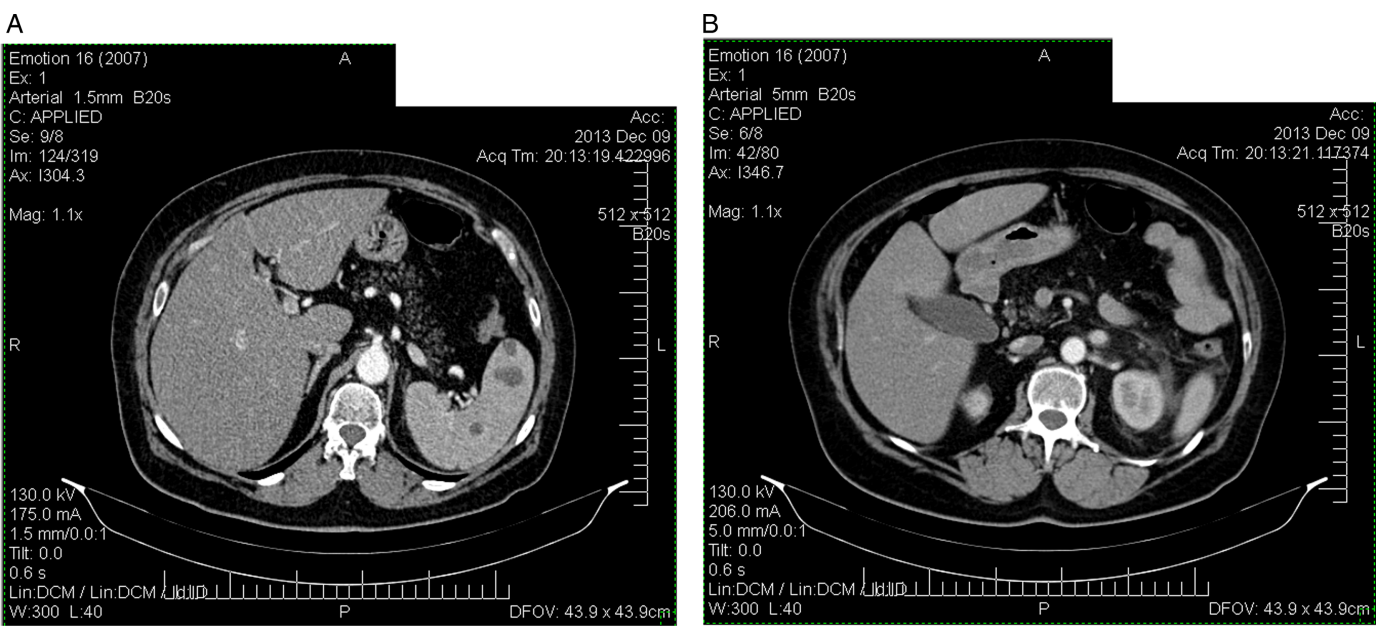

Figure 2 (A) CT scan of splenic abscess and (B) CT scan of pyelonephritis. 


\section{Learning points}

- Splenic abscess is a rare and severe complication of acute pyelonephritis.

- It is important to diagnose it quickly, despite the fact that it is difficult to establish the pathogenesis.

- Antibiotic treatment improves outcome.

Contributors The four authors are justifiably credited with authorship, according to the authorship criteria. In detail: LI is involved with conception, design, analysis and interpretation of data, drafting of the manuscript, final approval given; $\mathrm{CO}$ is involved with acquisition of data, analysis and interpretation of data, final approval given; $\mathrm{SI}$ is involved with acquisition of data, critical revision of manuscript, final approval given; LT is involved with conception, design, analysis and interpretation of data, drafting of the manuscript, final approval given.

Competing interests None.

Patient consent Obtained.

Provenance and peer review Not commissioned; externally peer reviewed.

\section{REFERENCES}

1 Yeh J-T, Yeh T-S. Splenic abscess: a rare sequel to renal abscess caused by staghorn calculi. Br J Urol 1997;80:504-5.

2 Fotiadis $C$, Lavranos $G$, Patapis $P$, et al. Abscesses of the spleen: report of three cases. World J Gastroenterol 2008;14:3088-91.

3 Saber A. Multiple splenic abscesses in a rather healthy woman: a case report. Cases J 2009:2:7340

Copyright 2014 BMJ Publishing Group. All rights reserved. For permission to reuse any of this content visit

http://group.bmj.com/group/rights-licensing/permissions.

BMJ Case Report Fellows may re-use this article for personal use and teaching without any further permission.

Become a Fellow of BMJ Case Reports today and you can:

- Submit as many cases as you like

- Enjoy fast sympathetic peer review and rapid publication of accepted articles

- Access all the published articles

- Re-use any of the published material for personal use and teaching without further permission

For information on Institutional Fellowships contact consortiasales@bmjgroup.com

Visit casereports.bmj.com for more articles like this and to become a Fellow 